\title{
A DETAILED ANALYSIS OF THE RAPID CHANGES IN ICE-CORE PARAMETERS DURING THE LAST ICE AGE
}

by

T. Staffelbach, B. Stauffer and H. Oeschger

(Physikalisches Institut, Universität Bern, $\mathrm{CH}-3102$ Bern, Sidlerstraße 5, Switzerland)

\begin{abstract}
Results from deep Greenland ice cores show rapid changes in several parameters in the deepest part. The most probable explanation for these variations is a fast-changing climate during part of the last glaciation. The question arises, however, of whether the observed changes in the ice cores could also be due to, or at least be influenced by, discontinuities in the stratigraphy. We present new $\mathrm{CO}_{2}$ and $\delta^{18} \mathrm{O}$ data from the Camp Century and Dye 3 deep ice cores. The data show rapid changes in $\mathrm{CO}_{2}$ and $8^{18} \mathrm{O}$ in both cores. One transition which was investigated in detail seems to be more rapid in the ice core from Dye 3 than in the Camp Century core. The broadening of a sharp $\delta^{18} \mathrm{O}$ transition due to molecular diffusion is discussed. Since this broadening is larger than the observed width of the transition, we discuss the possibility of a mechanism that can produce stratigraphic disturbances on a small scale. This mechanism is based on a calculation of the compression of horizontal layers which have equal density but different viscosities.
\end{abstract}

\section{INTRODUCTION}

In ice sheets, precipitations are clearly archived and stratified layer by layer. The snow layers become compacted under the load and are transformed into ice. As the ice moves deeper into the ice sheet, the layers thin continuously over time. Precipitations from the past, with all the information they contain about the climate and environment of their epoch, can be recovered by ice-core drilling. The ice flow is slow and generally laminar. However, the question of whether the flow is laminar also in the deepest layers has been discussed by different authors (Boulton 1983, Robin 1983, Johnsen and Robin 1983). This paper is a further contribution to the discussion. We are especially interested in whether the stratigraphy is well preserved in the ice core from Dye 3 (south Greenland) in the depth interval $1950-1850 \mathrm{~m}$ below surface, i.e. $87-187 \mathrm{~m}$ above bedrock. This depth interval is characterized by abrupt changes in several parameters observed in the ice core.

A main goal of this paper is to discuss why there is some doubt that this section of the ice core contains an undisturbed stratigraphy. The paper is based mainly on $\delta^{18} \mathrm{O}$ and $\mathrm{CO}_{2}$ measurements, which are presented in the first part. In the second part, estimates of the broadening of a transition zone due to molecular diffusion are discussed. In the third part, a mechanism which may be the cause of local disturbances in the stratigraphy will be discussed. We will estimate to what extent this mechanism can explain the measured abruptness of the observed $8^{18} \mathrm{O}$ and $\mathrm{CO}_{2}$ signals.

RAPID CLIMATIC CHANGES AND
MEASUREMENTS NEW
Until now the rapid changes, as they have been
measured in the depth interval 1950-1850 $\mathrm{m}$ below the
surface of the Dye 3 ice, are described in the literature as
having the following characteristics: the depth interval
corresponds to an estimated time interval of $70000-30000$
years B.P. (Dansgaard and others 1982). Large-amplitude
oscillations of the $\delta^{18} \mathrm{O}$ record have been observed

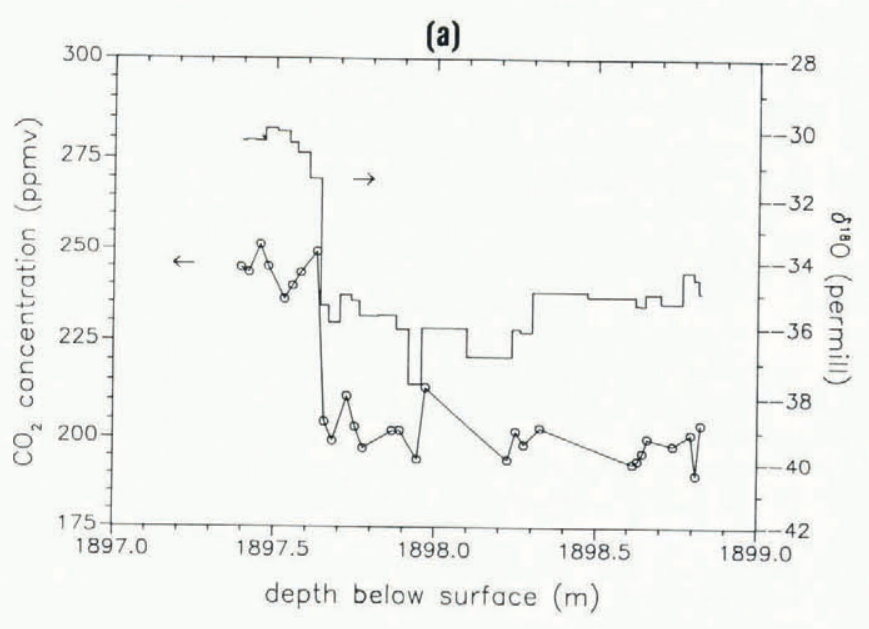

(b)

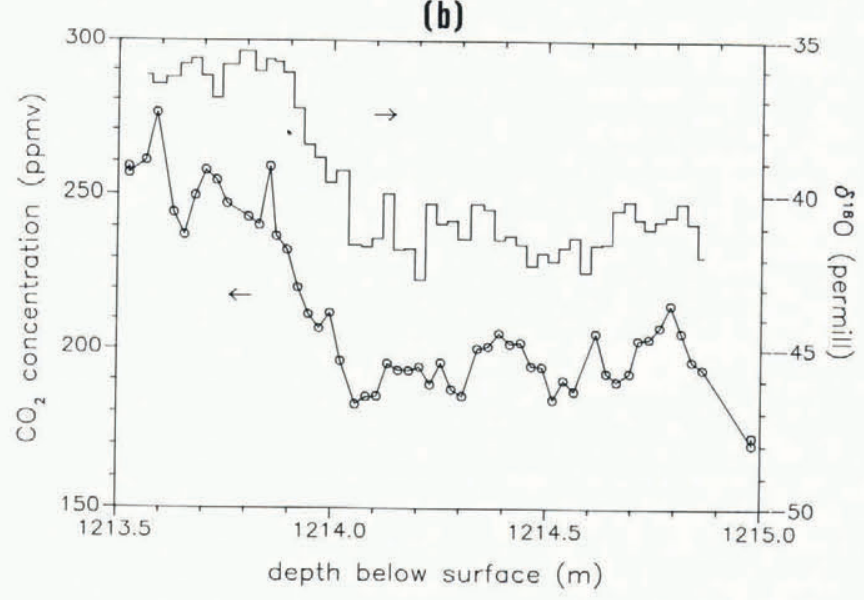

Fig.1. $\delta^{18} \mathrm{O}$ signal and $\mathrm{CO}_{2}$ concentration versus depth for Dye 3 (a) and Camp Century (b). The two transitions are believed to represent the same climatic event.

(Dansgaard and others 1984). Parallel to the $\delta^{18} \mathrm{O}$ variations of the order of $5 \%$, the dust content changes from the order of $0.3 \mathrm{mg} /\left(\mathrm{kg}\right.$ ice) for sections with high $\delta^{18} \mathrm{O}$ (relatively warm climate) to the order of $1.5 \mathrm{mg} /(\mathrm{kg}$ ice) for sections with low $\delta^{18} \mathrm{O}$ values (Dansgaard and others 1984). The concentrations of $\mathrm{Cl}^{-}, \mathrm{NO}_{3}^{-}$and $\mathrm{SO}_{4}{ }^{2-}$ all show significant variations, which correlate with the $\delta^{18} \mathrm{O}$ variations that have been measured (Finkel and Langway 1985). High concentrations of these parameters are found in sections with low $\delta^{18} \mathrm{O}$ values. In this depth interval the concentrations vary by a factor of about 1.5 for $\mathrm{Cl}^{-}$and $\mathrm{NO}_{3}{ }^{-}$and about 4 for $\mathrm{SO}_{4}{ }^{2-}$. In the depth interval 1900$1860 \mathrm{~m}$ the $\mathrm{CO}_{2}$ concentration of air extracted from ice-core samples shows significant variations of the order of $50 \mathrm{ppm}$ volume which also correlate with the observed ${ }_{8}^{18} \mathrm{O}$ variations (Stauffer and others 1984). 
The conclusion so far is that during this period there was a bistable climate in Greenland, accompanied by changes in the global atmospheric $\mathrm{CO}_{2}$ concentration.

In order to check this interpretation, we performed new detailed measurements on $\mathrm{CO}_{2}$ and $\delta^{18} \mathrm{O}$ with a resolution of $0.025 \mathrm{~m}$. We compared two transitions, one from the Dye 3 ice core (depth interval 1898-1897.4 m below surface) and another one from the Camp Century ice core (depth interval 1214.5-1213.5 m below surface). Following a correlation of the $\delta^{18} \mathrm{O}$ records from the Dye 3 and Camp Century ice cores which was suggested by Dansgaard and others (1982), this transition should correspond to the same climatic event. The measured $\mathrm{CO}_{2}$ concentrations and the $\delta^{18} \mathrm{O}$ values of the transition from the Dye 3 core, which is especially abrupt, and the transition from the Camp Century core are shown in Figure 1.

\section{REASONS FOR QUESTIONING AN UNDISTURBED}

\section{STRATIGRAPHY}

If parameters in ice cores show great changes over short depth intervals, we generally assume that the climatic conditions, reflected by the corresponding parameter, have changed over a short time. There are certainly some climatic restrictions on how fast a climatic parameter may change. We will not consider any such restriction, because it is also possible that recorded climatic parameters change suddenly from snow layer to snow layer, due to missing accumulation over a long period. For Dye 3, which at present has an accumulation rate of $0.5 \mathrm{~m}$ water equivalent/year, it is very unlikely that the net accumulation was zero or negative during a particular period. But even if we consider this unlikely situation as possible, if the shape of a signal of a climatic parameter is like a step function at the beginning, it will be smoothed by molecular diffusion with increasing time and depth. If the width of an observed transition at a certain depth is smaller than the predicted width, taking the molecular diffusion into account, it is a strong indication of irregularities in the stratigraphy.

The new results call into question the interpretation of the observed variations in terms of climatic events with a time history as indicated by the age-depth relation. In the Dye 3 ice core the transition of the $\delta^{18} \mathrm{O}$ value by $5 \%$ and of the $\mathrm{CO}_{2}$ concentration by $50 \mathrm{ppm}$ volume occurs from one sample to the next, i.e. within $0.025 \div 0.05 \mathrm{~m}$. Assuming an undisturbed stratigraphy and a regular annual accumulation during the last ice age of about 2.5 times less than the present-day value of $0.5 \mathrm{~m}$ w.e., $0.025 \mathrm{~m}$ corresponds to about 13 years' accumulation. Taking the width of the transition of $0.45 \mathrm{~m}$ and making the same assumptions for the Camp Century core in respect of the change in accumulation, the resulting period is 56 years.

The transition in the Dye 3 ice core, at least for $\delta^{18} \mathrm{O}$ and $\mathrm{CO}_{2}$, is very rapid. Allowing for molecular diffusion, one would expect slower transitions, even if they were originally step functions 40000 years ago.

The coefficient for self-diffusion $\mathrm{D}_{4}$ of $\mathrm{H}_{2} \mathrm{O}$ in single-crystal ice at $-20^{\circ} \mathrm{C}$ is about $6 \times 10^{-16} \mathrm{~m}^{2} \mathrm{~s}^{-1}$ (Hobbs 1974). If there is a steplike transition of the $\delta^{18} \mathrm{O}$ signal at time zero, the characteristic width $\langle x\rangle$ of the transition (from 4 to $88 \%$ of the initial step) after time $t$ is, according to Crank (1975):

$$
\langle\mathrm{x}\rangle \approx 4\left(\mathrm{D}_{\mathrm{v}} \mathrm{t}\right)^{\frac{1}{2}}
$$

The value for $\langle x\rangle$ is $0.11 \mathrm{~m}$ for an age of 40000 years. However, this formula does not take into account the thinning of annual layers due to the flow of the ice. The thinning of the annual layers increases the rate of changes in ice-core parameters, which counter-balances to some extent the diffusion process. In order to take this into account, we applied the flow model of Dansgaard and others (1969). We assumed a constant accumulation rate and that $\mathrm{h}$ (defined as the height above bedrock, where the horizontal velocity is constant) was $400 \mathrm{~m}$. The accumulation rate was much smaller during the glacial period, which is the longer part of the period under consideration. We selected a value of $0.25 \mathrm{~m}$ w.e. for the annual accumulation rate, which is only half the present value, in order to obtain an age of 40000 years for the $1898 \mathrm{~m}$ depth, in agreement with other estimates. The calculated characteristic width of a signal, which was a step at the surface, for the depth of $1898 \mathrm{~m}$ is about $0.078 \mathrm{~m}-$ a factor of 3 more than the $0.025 \mathrm{~m}$ observed in the Dye 3 core.

The transition observed in the Camp Century core is less sharp, about $0.45 \mathrm{~m}$, although the calculations indicate that the width should be about the same as for the Dye 3 core $(0.08 \mathrm{~m})$. Therefore there is no contradiction of the molecular-diffusion results for this transition in the Camp Century core. On the basis of the measurements and the estimates of the characteristic diffusion width we conclude that the transition analysed in the Dye 3 core is disturbed in the stratigraphy due to irregular flow characteristics. Since not all transitions are so abrupt, it is possible that only some of them are affected by irregularities in the flow behaviour.

Apart from the fact that the transition apparently did not have the same duration at Dye 3 and at Camp Century, although they are supposed to reflect the same climatic event, there are other points which indicate that the stratigraphy may be disturbed:

The measured $\delta^{18} \mathrm{O}$ and $\mathrm{CO}_{2}$ changes are assumed to correlate for the Dye 3 core as well as for the Camp Century core. Due to the difference between the gas age and the age of the surrounding ice, which is about 90 years for Dye 3 (present-day conditions), one would expect a depth difference of about $0.6 \mathrm{~m}$ between the two transitions, if the $\delta^{18} \mathrm{O}$ and $\mathrm{CO}_{2}$ change occurred simultaneously (130 years and $1 \mathrm{~m}$ respectively for Camp Century). If the $\delta^{18} \mathrm{O}$ change had accidentally preceeded the $\mathrm{CO}_{2}$ transition by 90 years, we would expect to observe a synchronous transition of both signals at the same depth in the Dye 3 ice core, but in the Camp Century core we would still have a phase shift of $0.49 \mathrm{~m}$ if the $\delta^{18} \mathrm{O}$ change also preceeded the $\mathrm{CO}_{2}$ transition by 90 years. This is well above the resolution of $0.025 \mathrm{~m}$.

Most climatic changes can be hemispheric or regional events, but atmospheric $\mathrm{CO}_{2}$ concentration variations have to be global, due to the small inter-hemispheric $\mathrm{CO}_{2}$-concentration gradients in the atmosphere. The same number of changes with the same amplitudes has therefore to be observed in both hemispheres. However, no changes of the magnitude of those in the Dye 3 ice core have been observed in an ice core fom Byrd Station (Antarctica) (Neftel and others, in press).

With reference to the points above, we discuss whether irregularities or discontinuities in the stratigraphy of the ice sheet can lead to abrupt transitions. Two orders of stratigraphic disturbances have to be distinguished:

Large-scale disturbances, e.g. folding, which could produce a sequence of alternating layers of Holocene and Pleistocene ice and which would completely destroy the stratigraphy (below the Holocene-Pleistocene transition).

Small-scale disturbances, which can cause local irregularities and lead to a change in layer thicknesses or local removal of certain layers.

\section{There is evidence against large-scale disturbances:}

Layers representing the relatively warm periods (high $\delta^{18} \mathrm{O}$ values) do not have the same values characteristic of the measured parameters $\left(8^{18} \mathrm{O}\right.$, dust concentration, $\mathrm{SO}_{4}{ }^{2-}, \mathrm{NO}_{3}{ }^{-}$, $\mathrm{Cl}^{-}$and $\left.\mathrm{CO}_{2}\right)$ as Holocene ice. The values measured in these layers cannot be explained, without contradiction, by any mixture of Holocene and Pleistocene ice.

The sequence of layers at Dye 3 and at Camp Century is very similar, although the two locations are $1400 \mathrm{~km}$ apart and the bedrock has quite different contours (Dansgaard and others 1985).

Comparing the shape of the dust concentration and the $\delta^{18} \mathrm{O}$ values, the dust concentrations increase less quickly (Dansgaard and others 1984). After a folding, the shapes would initially look the same. But because the dispersion due to molecular diffusion is larger for the $\delta^{18} \mathrm{O}$ signal than for the dust concentration, the reverse situation would be expected. The increase in the $\delta^{18} \mathrm{O}$ value should be broader than the corresponding change in the dust. 
Folding in the ice near Dye 3 was investigated by Whillans and Jezek (1987). According to their work, there are no irregularities in the stratigraphy which are due to large-scale folding, at least in the upper $1000 \mathrm{~m}$ of the ice sheet.

However, small local disturbances cannot be excluded. The question of whether stratified layers with uniform density but different viscosity $\mu$ show any irregular flow characteristics has been investigated by several authors (Biot 1961, Smith 1976, 1977 and 1979, Cobbold 1976). These models have already been applied to glaciological problems by other authors (Sanderson 1978, Collins and McCrae 1985), who investigated mainly surface problems. We want to apply the model to the ice layers near the bottom.

We based our work on a two-dimensional model for incompressible fluids, following Smith (1975 and 1977) to a large extent. In this model, a layer of viscosity $\mu_{2}$ is embedded in a medium with viscosity $\mu_{1}$ (Fig.2). In the following, subscript 1 corresponds to the surrounding material and subscript 2 to the embedded layer.

We use the following symbols:

\section{$\mu_{1}, \mu_{2}$ : viscosities of the two materials}

$\mathrm{n}_{1}, \mathrm{n}_{2}$ : power-law exponents of Glenn's Law

$H(x, t)$ : thickness of the embedded layer

$\mathrm{u}(\mathrm{x}, \mathrm{y})$ : horizontal velocity

$\mathrm{v}(\mathrm{x}, \mathrm{y})$ : vertical velocity

$y= \pm L$ : positions of the two confining plates

$\mathrm{V}^{*} \quad$ : velocity of the two confining planes

a(t) : amplitude of a disturbance at the interface

$\lambda(t) \quad$ : wavelength of the disturbance

Four possible kinds of instability occur. We will only discuss the case called boudinage, which is pinch-and-swell instability. Boudinage occurs where the embedded layer is more competent and the compression is perpendicular to the bedding.

The growth of a periodic disturbance at the interface is described in the following way:

$$
\frac{d a}{a}=-g \frac{d H}{H}
$$

where $\mathrm{g}$ is the total growth rate of the wavelength with the largest growth.

In the case where the disturbance does not grow, $\mathrm{g}$ is -1 . The factor $g$ is a function of:

the wave number $\alpha=2 \pi / \lambda$ of the disturbance, the viscosity ratio $\mathrm{m}=\mu_{2} / \mu_{1}$ of the two layers, the power-law exponents $n_{1}, n_{2}$ of the materials, the strain-rate $\mathrm{dU} / \mathrm{dx}$.

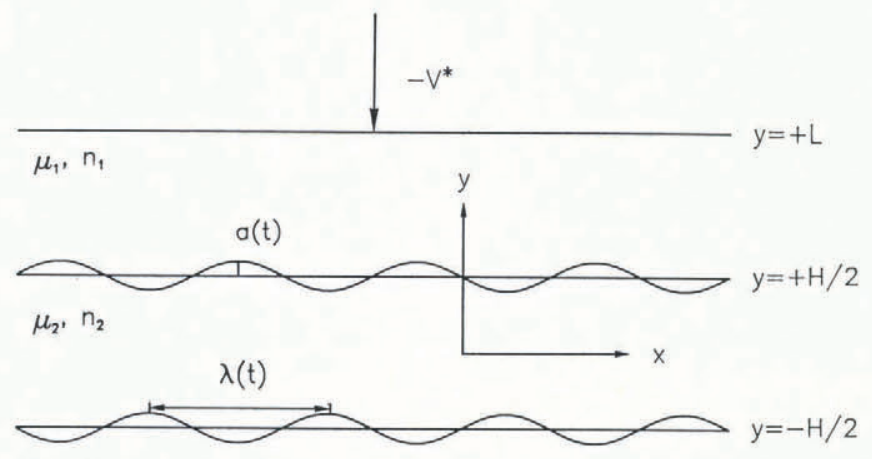

$\mu_{1}, n_{1}$

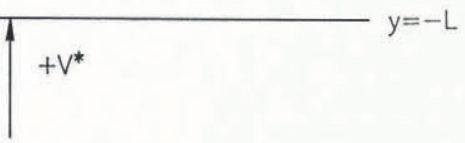

Fig.2. Description of the model used.
Ignoring the dependence of $\mathrm{g}$ on $\alpha$, Equation 1 can be integrated to

$$
\ln \frac{\mathrm{a}}{\mathrm{a}_{0}}=\mathrm{g} \ln \frac{\mathrm{H}_{0}}{\mathrm{H}}
$$

To take reasonable values for the viscosities and the power-law exponent we apply work by Shoji and Langway (1985[a]). They report flow parameters changing with depth for the Dye 3 ice core. The enhancement factor (defined as measured strain) versus theoretically expected strain varies between 1 and 15. The measurements of this factor have not been made at the same resolution as isotopic and chemical analyses and the accurate ratio of the enhancement factor between layers from cold periods and layers from warm periods is not known precisely. Since the enhancement factor shows drastic variations in ice from the last ice age, mainly between 5 and 10 , we assume that layers from warm periods (where there is less dust and fewer soluble impurities) have a viscosity about twice that for layers from cold periods. Shoji and Langway also calculated the power-law exponents, which varied between 2.7 and 3 . In the following we take a value of 3 for $n_{1}$ and $n_{2}$ and a value of 2 for $\mathrm{m}$.

According to Smith (1977), the growth rate of a disturbance is largest if the ratio of the wavelength to the layer thickness lies between 4 and 10 for the condition that $\mathrm{m}$ is smaller than 10 . The maximal growth rate $\mathrm{g}$ varies between -0.7 and 2 for different sets of $\left(n_{1}, n_{2}\right)$, if these two parameters are between 1 and 20. As a rough estimate, we assume that a layer representing a "warm" period was originally ice $200 \mathrm{~m}$ thick, and was compressed into a layer $0.8 \mathrm{~m}$ thick at a depth of $1898 \mathrm{~m}$. The wavelength of the disturbance with maximum growth rate is between 0.8 and $2 \mathrm{~km}$ close to the surface, where the layer thickness is $200 \mathrm{~m}$, and only between 3 and $8 \mathrm{~m}$ at $1898 \mathrm{~m}$ depth, due to the reduced layer thickness. Rough calculations show that the growth rate $\mathrm{g}$ is only significantly different from zero if the typical wavelength of the disturbance is larger than $\lambda_{\max } / 2$ and smaller than $2 \lambda_{\max }$. The mean value of $\mathrm{g}$ for compression by a factor of 4 is estimated to be 0.3 for this compression interval. Therefore we have:

$$
\mathrm{a} / \mathrm{a}_{0}=\left(\mathrm{H} / \mathrm{H}_{0}\right)^{-\mathrm{g}}
$$

If a disturbance at the surface had an amplitude of $1 \mathrm{~m}$ (only $0.5 \%$ of the layer thickness), the amplitude at $1898 \mathrm{~m}$ would be $1.50 \mathrm{~m}$, which is more than the layer thickness! This rough estimate is based on several assumptions. It is quite possible that we have underestimated the growth of the disturbance.

Nevertheless the estimated growth of the disturbance can lead to small local discontinuities in the stratigraphy, because material in the transition zone has to be moved horizontally due to the growth of the disturbance (Smith 1979).

\section{CONCLUSIONS}

There are transitions in the deep part of the Dye 3 ice core which are so abrupt that they cannot be explained either by rapid climatic changes or by missing or negative accumulation during a particular period. Our estimates show that layers with different viscosities can be responsible for disturbances. An effect which is called boudinage in geology leads to an amplification of pinch-and-swell structures under certain circumstances and therefore leads to a locally disturbed time-scale. The effect seems to be too small to influence the stratigraphy on a large scale, but it may be significant on a small scale. Therefore it does not influence the dating of ice cores substantially, since pinch-and-swell structures are probably statistically distributed along a core. On the other hand, it limits the possibility of investigating in great detail climatic behaviour during transitions. It would be very interesting to look for boudinage structures at the ice margin. There, however, it will be difficult to separate this disturbance from the ones created by the bedrock. It may be possible to check whether the stratigraphy is disturbed by the mechanisms we have discussed, which therefore result in rapid variations, by 
drilling two parallel ice cores in central Greenland. It would be worth while to compare, in great detail, the depth intervals which correspond to the rapid transitions observed in the Dye 3 core.

\section{ACKNOWLEDGEMENTS}

The $\delta^{18} \mathrm{O}$ measurements were performed by Kurt Hänni. This work was supported by the U.S. National Science Foundation and by the Swiss National Science Foundation.

\section{REFERENCES}

Boulton G S 1983 Debris and isotopic sequences in basal layers of polar ice sheets. In Robin $\mathrm{G}$ de $\mathrm{Q}(e d)$ The climatic record in polar ice sheets. Cambridge etc, Cambridge University Press: 83-89

Cobbold P R 1976 Unified theory of the onset of folding, boudinage, and mullion structure: discussion and reply. Discussion. Geological Society of America. Bulletin 87: 1663

Collins I F, McCrae I R 1985 Creep buckling of ice shelves and the formation of pressure rollers. Journal of Glaciology 31(109): 242-252

Crank J 1975 The mathematics of diffusion. Oxford and London, Clarendon Press

Dansgaard W, Johnsen S J 1969 A flow model and a time scale for the ice core from Camp Century, Greenland. Journal of Glaciology 8(53): 215-223

Dansgaard W and 6 others 1982 A new Greenland deep ice core. Science 218(4579): 1273-1277

Dansgaard W and 6 others 1984 North Atlantic climatic oscillations revealed by deep Greenland ice cores. In Hansen J E, Takahashi $\mathrm{T}$ (eds) Climate processes and climate sensitivity. Washington, DC, American Geophysical Union: 288-298 (Geophysical Monograph 29)

Dansgaard W, Clausen H B, Gundestrup N, Johnsen S J, Rygner C 1985 Dating and climatic interpretation of two deep Greenland ice cores. In Langway C C Jr, Oeschger $\mathrm{H}$, Dansgaard W (eds) Greenland ice core: geophysics, geochemistry and the environment. Washington, DC, American Geophysical Union: 71-76 (Geophysical Monograph 33)

Finkel R C, Langway C C Jr 1985 Global and local influences on the chemical composition of snowfall at Dye 3, Greenland: the record between 10 ka $\mathrm{B} P$ and 40 ka B P. Earth and Planetary Science Letters 73(2-4): 196-206

Fisher D A, Koerner R M 1986 On the special rheological properties of ancient microparticle-laden Northern Hemisphere ice as derived from bore-hole and core measurements. Journal of Glaciology 32(112): 501-510

Haefeli R 1961 Contribution to the movement and the form of ice sheets in the Arctic and Antarctic. Journal of Glaciology 3(30): 1133-1151

Hobbs P V 1974 Ice physics. Oxford and London, Clarendon Press

Johnsen S J 1977 Stable isotope homogenization of polar firn and ice. International Association of Hydrological Sciences Publication 118 (General Assembly of Grenoble 1975-Isotopes and Impurities in Snow and Ice): 210-219

Johnsen S J, Robin G de Q 1983 Diffusion of stable isotopes. In Robin $\mathrm{G}$ de $\mathrm{Q}(e d)$ The climatic record in polar ice sheets. Cambridge etc, Cambridge University Press: 57-63

Johnsen S J, Dansgaard W, Clausen H B, Langway C C Jr 1972 Oxygen isotope profiles through the Antarctic and Greenland ice sheets. Nature 235(5339): 429-434

Neftel A, Oeschger H, Staffelbach T, Stauffer B In press $\mathrm{CO}_{2}$ record in the Byrd ice core 50'000-5'000 b.p. Nature

Oeschger H, Stauffer B, Finkel R, Langway C C Jr 1985 Variations of the $\mathrm{CO}_{2}$ concentration of occluded air and of anions and dust in polar ice cores. In Sundquist E T, Broecker W S (eds) The carbon cycle and atmospheric $\mathrm{CO}_{2}$ : natural variations archean to present. Washington, DC, American Geophysical Union: 132-142 (Geophysical Monograph 32)

Overgaard S, Gundestrup N S 1985 Bedrock topography of the Greenland ice sheet in the Dye 3 area. In Langway C C Jr, Oeschger H, Dansgaard W (eds) Greenland ice core: geophysics, geochemistry and the environment. Washington, DC, American Geophysical Union: 49-56 (Geophysical Monograph 33)

Robin G de Q 1983 Radio-echo studies of internal layering of polar ice sheets. In Robin G de Q (ed) The climatic record in polar ice sheets. Cambridge etc, Cambridge University Press: 89-93

Sanderson T J O 1978 Thermal stresses near the surface of a glacier. Journal of Glaciology 20(83): 257-283

Schwander J Unpublished Lufteinschluss im Eis in Grönland und der Antarktis. Messung der elektrischen Leitfähigkeit von Eisproben für klimatologische Anwendungen. ( $\mathrm{PhD}$ thesis, Universität Bern, 1984)

Schwander J, Stauffer B 1984 Age difference between polar ice and the air trapped in its bubbles. Nature 311(5981): 45-47

Shoji H, Langway C C Jr 1985[a] Mechanical properties of fresh ice core from Dye 3. In Langway C C Jr, Oeschger $\mathrm{H}$, Dansgaard W (eds) Greenland ice core: geophysics, geochemistry and the environment. Washington, DC, American Geophysical Union: 39-48 (Geophysical Monograph 33)

Shoji H, Langway C C Jr 1985[b] The ice flow velocity profile for Dye 3, Greenland. Geophysical Research Letters 12(12): 797-800

Smith R B 1975 Unified theory of the onset of folding boudinage and mullion structure. Geological Society of America. Bulletin 86: 1601-1609

Smith R B 1976 Unified theory of the onset of folding boudinage and mullion structure: discussion and reply. Reply, Geological Society of America. Bulletin 87: 1663

Smith R B 1977 Formation of folds, boudinage, and mullions in non-Newtonian materials. Geological Society of America. Bulletin 88: $312-320$

Smith R B 1979 The folding of a strongly non-Newtonian layer. American Journal of Science 279: 272-287

Stauffer B, Hofer H, Oeschger H, Schwander J, Siegenthaler U 1984 Atmospheric $\mathrm{CO}_{2}$ concentration during the last glaciation. Annals of Glaciology 5: $160-164$

Stauffer B, Neftel A, Oeschger H, Schwander J $1985 \mathrm{CO}_{2}$ concentration in air extracted from Greenland ice samples. In Langway $\mathrm{C} \mathrm{C} \mathrm{Jr}$, Oeschger $\mathrm{H}$, Dansgaard $\mathrm{W}$ (eds) Greenland ice core: geophysics, geochemistry and the environment. Washington, DC, American Geophysical Union: 85-89 (Geophysical Monograph 33)

Weertman J 1968 Diffusion law for the dispersion of hard particles in an ice matrix that undergoes simple shear deformation. Journal of Glaciology 7(50): 161-165

Whillans I M, Jezek K C 1987 Folding in the Greenland ice sheet. Journal of Geophysical Research 92(B1): 485-493 